\title{
Treatment with tumour necrosis factor $\alpha$ antagonists in patients with rheumatoid arthritis induces anticardiolipin antibodies
}

\author{
T Jonsdottir, J Forslid, A van Vollenhoven, A Harju, S Brannemark, L Klareskog, \\ R F van Vollenhoven
}

See end of article for authors' affiliations

Correspondence to:

T Jonsdottir, MD,

Department of

Rheumatology, Karolinska

University Hospital, 17176

Stockholm, Sweden;

thorunn.jonsdottir@kus.se

Accepted

16 February 2004

Published online first

5 April 2004

\begin{abstract}
Objective: To determine the frequency and clinical impact of anticardiolipin antibodies (aCL) in patients with rheumatoid arthritis treated with infliximab and etanercept.

Methods: 121 patients from the Stockholm tumour necrosis factor $\alpha$ (TNF $\alpha$ ) follow up registry (STURE) treated with infliximab or etanercept were studied.

Results: At baseline $9 / 65(14 \%)$ infliximab and 10/56 (18\%) etanercept treated patients had positive aCL. After 3 months the frequencies of aCL positivity were $29 \%$ ( $p<0.05$ compared with baseline) and $27 \%$, respectively, and after 6 months $28 \%$ and $25 \%$. Increases were seen for both $\lg G$ and $\operatorname{lgM}$ aCL. Increasing age, a higher number of prior DMARDs, and higher DAS28 were predictors for the development of aCL. In the infliximab treated patients, $26 / 30(87 \%)$ aCL(-) but only $7 / 14(50 \%)$ aCL(+) patients met the ACR20 criteria $(p<0.05)$, and the frequency of treatment limiting infusion reactions in the $\mathrm{aCL}(+)$ patients was higher than expected (17\%). aCL positivity in the etanercept treated patients did not show such a clinical correlate. Four patients had thromboembolic events, of whom two were $\mathrm{aCL}(+)$ and two $\mathrm{aCL}(-)$. Conclusion: Frequencies of both $\lg \mathrm{M}$ and $\operatorname{lgG}$ aCL positivity increase in patients treated with these TNF $\alpha$ antagonists for 3 months or longer. Increasing age, a greater number of prior DMARDs and a greater disease activity at baseline are predictors for the development of $\mathrm{aCL}$. The development of aCL during treatment with infliximab, but not etanercept, is associated with worse clinical results and more frequent serious infusion reactions. aCL are an important class of autoantibodies associated with TNF $\alpha$ blocking therapy.
\end{abstract}

$\mathrm{T}$ umour necrosis factor $\alpha(\mathrm{TNF} \alpha)$ blocking agents are now widely used in the treatment of aggressive rheumatoid arthritis (RA) and have proved to be effective and relatively safe. ${ }^{1-10}$

Earlier studies have shown the induction of autoantibodies during treatment with TNF $\alpha$ blocking agents. ${ }^{11}$ Thus, antinuclear antibodies (ANA) have been described in 53-68\% and anti-double stranded DNA (anti-dsDNA) antibodies in 5-10\% of patients with RA treated with the TNF $\alpha$ blocking agent infliximab (Remicade). ${ }^{1-35}{ }^{11}$ In patients treated with etanercept (Enbrel) the same autoantibodies are seen in $11 \%$ and $5-13 \%$, respectively. ${ }^{78}$ Only limited data have been published about the induction of anticardiolipin antibodies (aCL) during TNF $\alpha$ blocking treatment. Thus, Elliott et al found aCL in one of 20 patients with RA treated with anti-TNF $\alpha$ (cA2) in an open trial lasting 8 weeks. ${ }^{4}$ Rankin et al measured the serological effects of repeated doses of the humanised anti-TNF $\alpha$ antibody CDP 571 in patients with RA and found that some patients develop positive aCL $(\operatorname{IgG}) .{ }^{12}$ Ferraccioli et al showed variations in aCL titres over time in etanercept treated patients with concomitant bacterial infection, where lowering of titres was seen after treatment with antibiotics. ${ }^{13}$ In the normal population (healthy blood donors) aCL are found in $2-6 \%$, and in an aging population in up to $12 \% .^{14}$ In patients with RA aCL have been found at even higher frequencies. ${ }^{16}{ }^{17} \mathrm{aCL}$, in general, are associated with thromboembolic disease, but their clinical significance in RA is uncertain and their presence has been considered to be a non-specific marker of activation of the immune system. ${ }^{18}$

In this study we assessed the frequency of aCL in patients with RA treated with infliximab or etanercept, and their relation to clinical outcomes.

\section{PATIENTS AND METHODS \\ Patients}

We retrospectively studied 121 patients from the Stockholm TNF $\alpha$ follow up registry (STURE), who were at least 18 years of age and fulfilled the1987 criteria for RA of the American College of Rheumatology (ACR). ${ }^{19}$ Treatment of these patients conventionally had failed and they then received treatment with the TNF $\alpha$ blocking agents infliximab $(n=65)$ or etanercept $(n=56)$. Over $90 \%$ of the patients receiving infliximab and $50 \%$ of those receiving etanercept were also treated with methotrexate $7.5-15 \mathrm{mg} /$ week. Infliximab was given according to standard protocol guidelines: $3 \mathrm{mg} / \mathrm{kg}$ at 0 , 2 , and 6 weeks and every 8th week thereafter. Etanercept $(25 \mathrm{mg})$ was given subcutaneously twice weekly.

\section{Blood samples and laboratory analyses}

Analyses for aCL, ANA, rheumatoid factor, and IgG anti-DNA were performed at baseline and after 3, 6, and 12 months of treatment. aCL was measured with an in-house enzyme linked immunosorbent assay (ELISA), calibrated against the Harris standard for IgG and IgM aCL, respectively. A rabbit antihuman IgG, $\gamma$ chain-specific conjugate, conjugated to horseradish peroxidase (Dako P 0214) was used. Results were given in $\mathrm{IU} / \mathrm{ml}$ and the cut off point was determined at $14 \mathrm{IU} / \mathrm{ml}$ in a healthy blood donor population. Low, medium, and high levels were defined as 14-20, 21-80, and >80 IU/ml

Abbreviations: aCL, anticardiolipin antibodies; $A C R$, American College of Rheumatology; ANA, antinuclear antibodies; DAS28, disease activity score; DMARDs, disease modifying antirheumatic drugs; ELISA, enzyme linked immunosorbent assay; RA, rheumatoid arthritis; STURE,

Stockholm TNF $\alpha$ follow up registry; TNF $\alpha$, tumour necrosis factor $\alpha$ 
Table 1 Predictors of aCL positivity at baseline and of seroconversion

\begin{tabular}{|c|c|c|}
\hline & $\begin{array}{l}\text { Positivity at } \\
\text { baseline }\end{array}$ & Seroconversion \\
\hline Age & NS & $<0.001$ \\
\hline Sex & $<0.01$ & NS \\
\hline Disease duration & NS & $<0.05$ \\
\hline No of prior DMARDs & NS & $<0.01$ \\
\hline MTX (n/y) & NS & NS \\
\hline Disease activity (DAS28) & NS & $<0.01$ \\
\hline RF (neg/pos) & $<0.05$ & NS \\
\hline ANA (neg/pos) & NS & NS \\
\hline \multicolumn{3}{|c|}{$\begin{array}{l}\mathrm{p} \text { Values are based on comparisons for aCL( }- \text { ) versus aCL( }+ \text { ) patients by } \\
\chi^{\wedge} 2 \text { test (for dichotomous variables) and by Student's } t \text { test (for } \\
\text { continuous variables). } \\
\text { NS, not significant. }\end{array}$} \\
\hline
\end{tabular}

respectively. ANA were assayed using HEp-2 cells as substrate (Immunoconcepts) and FITC antihuman IgG conjugate (Binding Site). IgG anti-DNA antibodies were measured with an ELISA (Pharmacia Diagnostics). Rheumatoid factor was measured by nephelometry (Beckman).

\section{Clinical outcomes}

The following clinical outcomes were measured at baseline and after 3, 6, and 12 months: swollen joint count, tender joint count, visual analogue scale for global assessment and pain by the patient, a five point Likert scale for physician's global assessment, Health Assessment QuestionnaireDisability Index ${ }^{20}$ and laboratory data (acute phase reactant values of $C$ reactive protein, erythrocyte sedimentation rate, and haemoglobin concentrations).

The ACR, response criteria (ACR20) $)^{21}$ and the EULAR response criteria based on disease activity score-28 (DAS28) ${ }^{22}$ were determined at baseline and after 3, 6, and 12 months of treatment.

\section{Adverse effects}

We analysed the frequency of treatment limiting infusion reactions and of thromboembolic events.

\section{Statistical analysis}

Statistical analysis was performed using Statview 5.0.1 software (SAS Corp, Cary, NC). Results of the analysis are reported as mean values and standard deviations (SD) and comparisons were performed using $\chi^{2}$ test and Student's $t$ test.

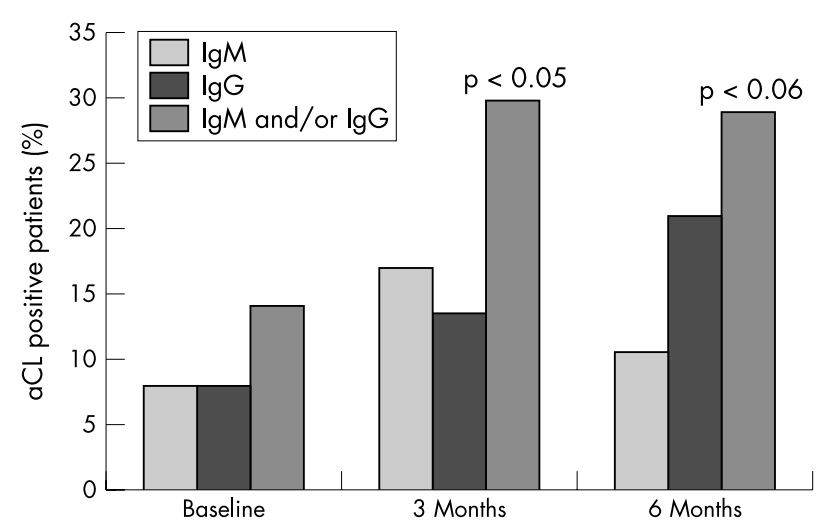

Figure 1 Percentage of $\mathrm{aCL}(+)$ patients at baseline and after 3 and 6 months of treatment with infliximab. Percentage positive for $\mathrm{lgG} \mathrm{aCL}$ : $\mathrm{p}<0.05$ for linear trend.

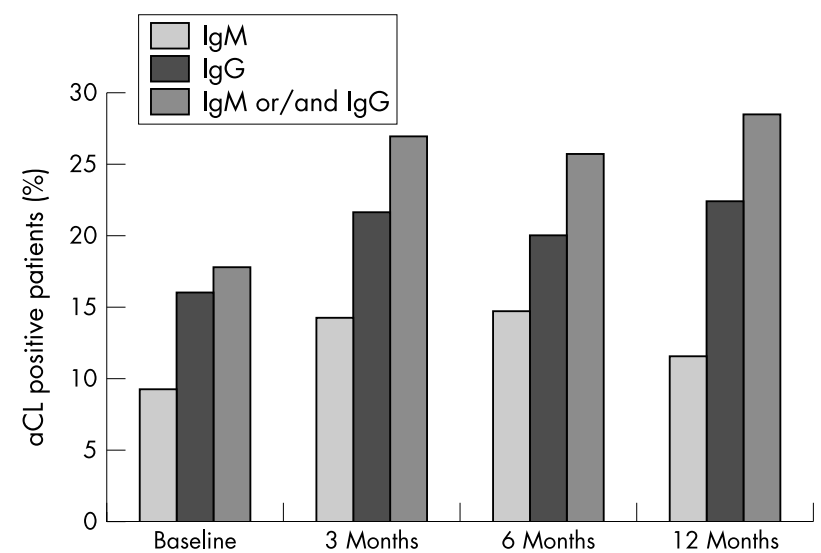

Figure 2 Percentage of aCL(+)patients at baseline and after 3, 6, and 12 months of treatment with etanercept.

\section{RESULTS}

\section{Characteristics of the patients}

Ninety eight women and 23 men were studied. The mean age was 52 years (range $21-81$ ), the mean disease duration was 14 years (range $1-43$ ), 90\% were seropositive, and the median number of prior disease modifying antirheumatic drugs (DMARDs) was five.

\section{Frequency of aCL increases during treatment with TNF $\alpha$ blockers}

At baseline 9/65 (14\%) infliximab and 10/56 (18\%) etanercept treated patients had positive IgM and/or IgG aCL, at low to medium levels. After 3 months the frequencies of aCL positivity were $29 \%(\mathrm{p}<0.05$ compared with baseline) and $27 \%$, respectively, and after 6 months $28 \%$ and $25 \%$, respectively. Increases were seen for both IgG and IgM aCL (figs 1 and 2). Increasing age, a greater number of prior DMARDs, and a greater disease activity at baseline by DAS28 were positive predictors for development of aCL after 3 months of treatment. No correlation was seen between ANA positivity and the development of aCL (table 1). The mean aCL IgM and IgG titres showed a small, non-significant increase over time (fig 3).

\section{aCL are associated with worse clinical results}

ACR responses and DAS values were studied in 44 infliximab treated patients. Twenty six of $30(87 \%)$ aCL $(-)$ patients were ACR20 responders while only 7/14 (50\%) aCL(+) patients met the ACR20 criteria $(\mathrm{p}<0.05)$ (fig 4). Assessment of the DAS28 response after 3 months showed that the aCL $(-)$ patients had a mean (SD) DAS28 of 3.6 $(0.15)$ compared with the aCL $(+)$ patients who had a mean DAS28 of $4.3(0.24) \quad(p<0.05)$. However, baseline DAS28 values were also higher in the aCL(+) patients and there were no significant differences between the changes in DAS28 in the two groups (not shown).

In etanercept treated patients, clinical responses were similar between $\mathrm{aCL}(+)$ and $\mathrm{aCL}(-)$ patients (data not shown).

\section{aCL are associated with more frequent adverse outcomes}

The frequency of treatment limiting infusion reactions in the $\mathrm{aCL}(+)$ patients was $17 \%$ compared with $5 \%$ in the entire $\mathrm{TNF} \alpha$ registry $(\mathrm{p}<0.05)$ (fig 5$)$. The adverse effects were fevers, chills, urticaria, chest pain, dyspnoea, sickness, flushing with headache, tachycardia, hypotension, and anaphylactic reactions. Four patients had thromboembolic events (three receiving infliximab, one receiving etanercept). 

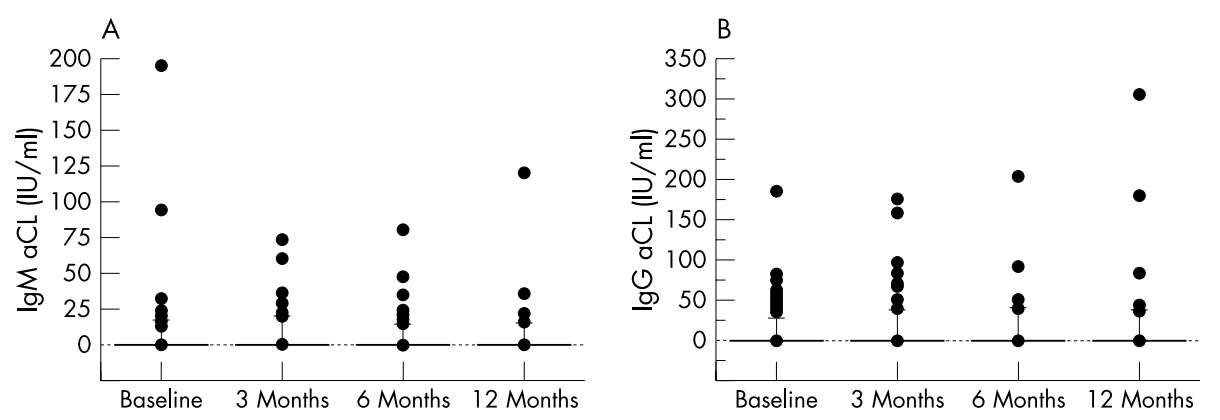

Figure 3 (A) $\operatorname{lgM~aCL}$ titres (IU/ml) in all patients at baseline and after 3, 6, and 12 months of treatment. (B) $\lg \mathrm{aCL}$ titres (IU/ml) in all patients at baseline and after 3,6 , and 12 months of treatment.

Two of these patients were $\mathrm{aCL}(+)$ and two $\mathrm{aCL}(-)$. Of the $\mathrm{aCL}(+)$ patients, one had a pulmonary embolus and the other a stroke. Thus, frequencies for thromboembolic events are $7 \%$ and $2.6 \%$ in the $\mathrm{aCL}(+)$ and $\mathrm{aCL}(-)$ patients, respectively, which is not statistically significant (relative risk $2.7,95 \%$ confidence interval 0.8 to 4.6 ).

\section{DISCUSSION}

In our patients we found a statistically significant increase in the frequency of IgM and/or IgG aCL positivity among patients treated with infliximab for 3 months or longer. Similar results were seen for etanercept, suggesting that this may be a class effect of the TNF $\alpha$ blocking agents. Previous studies on treatment with TNF $\alpha$ blocking agents and development of autoantibodies have mainly focused on ANA and anti-DNA. Thus, we believe that this is the first systematic description of increased aCL frequency in patients treated with TNF $\alpha$ antagonists.

A possible criticism of the study could be that patients treated with TNF $\alpha$ blocking agents might have reduced or discontinued glucocorticoid treatment and this might in itself allow the development of autoantibodies. Supporting this, a small but statistically significant decrease in mean glucocorticoid dosage was seen in these patients (not shown). However, the absolute change in dosage was small. Moreover, Lockshin et al showed that glucocorticoid treatment even at high doses did not change the presence of aCL nor did it lower the titres. ${ }^{23}$

One possible explanation for the induction of aCL positivity in patients treated with $\mathrm{TNF} \alpha$ blocking agents is that the down regulation of TNF $\alpha$ induces up regulation of interleukin 10 , which in turn activates autoreactive $\mathrm{B}$ cells ${ }^{24}$ and thus induces autoantibody production. Alternatively, lower levels of TNF $\alpha$ might lead to a generalised increase in Th2 activity, which even through other cytokine pathways might leads to B cell activation ${ }^{24}$ and autoantibody formation. Ferraccioli

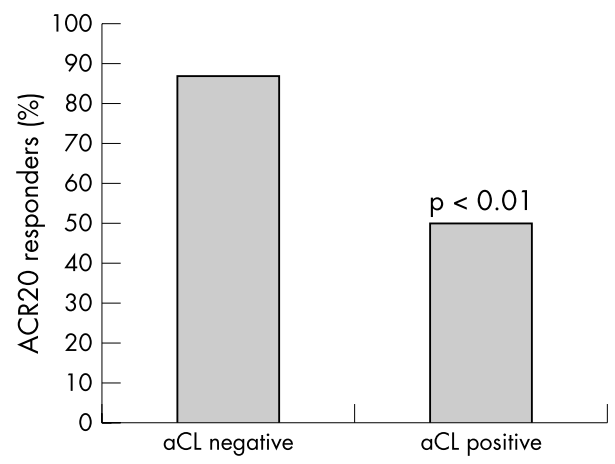

Figure 4 Percentage of ACR20 responders to treatment with infliximab in $\mathrm{aCL}(-)$ and $\mathrm{aCL}(+)$ patients. Comparison is by $\chi^{2}$ test. et al have shown a relationship between clinically overt infections and aCL formation. ${ }^{13}$ Thus, a third explanation might be that $\mathrm{TNF} \alpha$ blockade allows a subtle increase in bacterial stimuli from the environment, leading to increased aCL formation.

Increasing age, greater number of prior DMARDs, and more severe disease activity were predictors for the development of aCL in this study, but obviously, these factors are not independent.

We found that the development of aCL positivity during treatment with infliximab had prognostic significance because it was associated with worse clinical results and more frequent serious infusion reactions. However, it is unclear how the association between aCL positivity and clinical outcome is mediated. One could speculate that the precise immunopathologies of RA are different from patient to patient, and that in some patients autoreactive $B$ lymphocytes might have a more causal role. Such patients might therefore be less likely to respond to TNF $\alpha$ blockade and also more likely to produce aCL. Indirect evidence for the existence of such a patient group with more B cell dependent disease has come from clinical studies with the B cell ablative monoclonal antibody rituximab. ${ }^{25} 26$

In this study we found only a few patients with antidsDNA antibodies. However, it should be noted that we only measured IgG anti-dsDNA and not the IgM isotype, which in earlier studies was shown to be preferentially induced by TNF $\alpha$ blocking treatment. ${ }^{1-3}$ 6-8 11 Among our patients only one developed IgG anti-dsDNA antibodies (both by an ELISA and by the Crithidia luciliae test) during treatment with infliximab. This patient developed a lupus-like syndrome with pleuropericarditis.

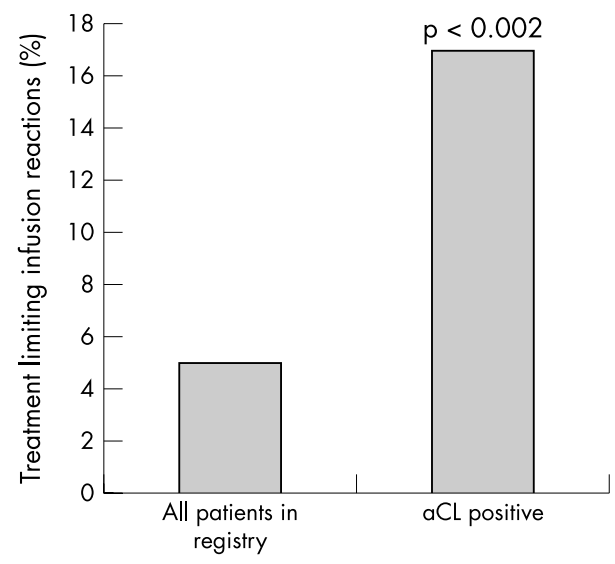

Figure 5 Percentage of treatment limiting infusion reactions in $\mathrm{aCL}(+)$ patients compared with all patients in the registry (infliximab treatment only). Comparison is by $\chi^{2}$ test. 
Our study may have some practical clinical implications. Although aCL in general are associated with an increased risk for thromboembolism, the small number of events in these patients did not allow us unequivocally to identify an increased risk. Continued long term follow up of patients treated with biological agents, such as is continuing through the Swedish ARTIS and STURE registries, is therefore of critical importance.

An important clinical question is whether all patients treated with the TNF $\alpha$ blocking agents should be screened for aCL. In this study, aCL positivity predicts less benefit from treatment with infliximab and a higher risk for a treatment limiting infusion reaction. Therefore, knowledge of aCL serology might, in principle, lead to a change in the risk/ benefit assessment and might affect the decision about which antirheumatic treatment to choose. This may become a more germane consideration if a significantly greater number of therapeutic choices become available, which may well be the case in a number of years.

Another question is what should be done if a patient develops aCL during treatment with TNF $\alpha$ blocking agents. We believe that such patients should be treated as all subjects with fortuitously detected aCL, and that the aCL titres should be followed up periodically if found to be positive. However, this does not necessarily mean that $\mathrm{aCL}(+)$ patients need to stop the TNF $\alpha$ blocking treatment.

In future studies, it might be interesting to look more closely at the general immunoglobulin production and even the production of antibodies against infliximab and etanercept in our patient group. It would also be interesting to see if the aCL(+) patients would respond better to $\mathrm{B}$ cell ablative therapy. We are also following up our patient cohort for a longer period of time to see if more patients develop these autoantibodies, the longer the treatment continues.

In summary, aCL are induced in patients with RA treated with the TNF $\alpha$ blocking agents infliximab and etanercept. A statistically significant increase in frequency is seen for IgM and IgG aCL already after 3 months of treatment with infliximab. Etanercept treated patients show the same pattern, suggesting a class effect of the TNF $\alpha$ blocking agents. aCL positivity in patients treated with infliximab predicts worse clinical outcomes and more frequent treatment limiting infusion reactions. aCL are an important class of autoantibodies associated with TNF $\alpha$ blocking therapy.

\section{ACKNOWLEDGEMENTS}

The Swedish TNF $\alpha$ follow up registry is owned by the Swedish Rheumatological Society (SRF), and supported by grants from Wyeth Lederle and Schering-Plough. This study was supported by the Swedish Rheumatism Association.

\footnotetext{
Authors' affiliations

T Jonsdottir, A van Vollenhoven, A Harju, S Brannemark, L Klareskog,

R F van Vollenhoven, Department of Rheumatology, Karolinska

Hospital, Stockholm, Sweden

J Forslid, Department of Clinical Immunology, Karolinska Hospital, Stockholm, Sweden

\section{REFERENCES}

1 Maini RN, Breedveld FC, Kalden JR, Smolen JS, Davis D, Macfarlane JD, et al. Therapeutic efficacy of multiple intravenous infusions of anti-tumour necrosis factor $\alpha$ monoclonal antibody combined with low-dose weekly methotrexate in rheumatoid arthritis. Arthritis Rheum 1998;41:1552-6.

2 Maini RN, St Clair EW, Breedveld F, Furst D, Kalden J, Weisman M, et al. Infliximab (chimeric anti-tumour necrosis factor $\alpha$ monoclonal antibody) versus
}

placebo in rheumatoid arthritis patients receiving concomitant methotrexate: a randomised phase III trial. Lancet 1999;354:1932-9.

3 Lipsky PE, van der Heijde DM, St Clair EW, Furst DE, Breedveld FC, Kalden JR, et al. Infliximab and methotrexate in the treatment of rheumatoid arthritis. N Engl J Med 2000;343:1594-602.

4 Elliott MJ, Maini RN, Feldmann M, Long-Fox A, Charles P, Bijl H, et al. Repeated therapy with monoclonal antibody to tumour necrosis factor- $\alpha$ (cA2) in patients with rheumatoid arthritis. Lancet 1994;344:1125-7.

5 De Rycke L, Kruithof E, Van Damme N, Hoffman IE, Van den Bossche N, Van den Bosch F, et al. Antinuclear antibodies following infliximab treatment in patients with rheumatoid arthritis or spondylarthropathy. Arthritis Rheum 2003;48:1015-23.

6 Elliott MJ, Maini RN, Feldmann M, Long-Fox A, Charles P, Katsikis P, et al. Treatment of rheumatoid arthritis with chimeric monoclonal antibodies to tumor necrosis factor- $\alpha$. Arthritis Rheum 1993;36:1681-90.

7 Weinblatt ME, Kremer JM, Bankhurst AD, Bulpitt KJ, Fleischmann RM, Fox RI, et al. A trial of etanercept, a recombinant tumour necrosis factor receptor:Fc fusion protein, in patients with rheumatoid arthritis receiving methotrexate. N Engl J Med 1999;340:253-9.

8 Moreland LW, Schiff MH, Baumgartner SW, Tindall EA, Fleischmann RM, Bulpitt KJ, et al. Etanercept therapy in rheumatoid arthritis: a randomised, controlled trial. Ann Intern Med 1999;130:478-86.

9 Moreland LW, Baumgartner SW, Schiff MH, Tindall EA, Fleischmann RM, Weaver AL, et al. Treatment of rheumatoid arthritis with a recombinant human tumor necrosis factor receptor (p75)-Fc fusion protein. N Engl J Med 1997;337:141-7.

10 Bathon JM, Martin RW, Fleischmann RM, Tesser JR, Schiff MH, Keystone EC, et al. A comparison of etanercept and methotrexate in patients with early rheumatoid arthritis. N Engl J Med 2000;343:1586-93.

11 Charles PJ, Smeenk RJ, De Jong J, Feldmann M, Maini RN. Assessment of antibodies to double-stranded DNA induced in rheumatoid arthritis patients following treatment with infliximab, a monoclonal antibody to tumor necrosis factor- $\alpha$ : findings in open-label and randomised placebo-controlled trials. Arthritis Rheum 2000;43:2383-90.

12 Rankin ECC, Choy EHS, Ehrenstein MR, Ravirajan CT, Sopwith M, Vetterlein $O$, et al. Serological effects of repeated doses of an engineered human anti-TNF- $\alpha$ antibody, CDP571, in patients with rheumatoid arthritis [abstract]. Arthritis Rheum 1995;38(suppl):S279

13 Ferraccioli GF, Mecchia F, Di Poi E, Fabris M. Anticardiolipin antibodies in rheumatoid patients treated with etanercept or conventional combination therapy: direct and indirect evidence of a possible association with infections. Ann Rheum Dis 2002:82:358-61

14 Shi W, Krilis SA, Chong BH, Gordon S, Chesterman CN. Prevalence of lupus anticoagulant and anticardiolipin antibodies in a healthy population. Aust N Z J Med 1990;20:231-6.

15 Fields RA, Toubbeh H, Searles RP, Bankhurst AD. The prevalence of anticardiolipin antibodies in a healthy elderly population and its association with antinuclear antibodies. J Rheumatol 1989;16:623-5.

16 Keane A, Woods R, Dowding V, Roden D, Barry C. Anticardiolipin antibodies in rheumatoid arthritis. Br J Rheumatol 1987;26:346-50.

17 Wolf P, Gretler J, Aglas F, Auer-Grumbach P, Rainer F. Anticardiolipin antibodies in rheumatoid arthritis: their relation to rheumatoid nodules and cutaneous vascular manifestations. Br J Dermatol 1994;131:48-51.

18 Kapiotis S, Speiser W, Pabinger-Fasching I, Kyrle PA, Lechner K. Anticardiolipin antibodies in patients with venous thrombosis. Haemostasis 1991;21:19-24.

19 Arnett FC, Edworthy SM, Bloch DA, McShane DJ, Fries JF, Cooper NS, et al. The American Rheumatism Association 1987 revised criteria for the classification of rheumatoid arthritis. Arthritis Rheum 1988;31:315-24.

20 Fries JF, Spitz PW, Young DY. The dimensions of health outcomes: the Health Assessment Questionnaire, Disability and Pain Scale. J Rheumatol 1982;9:789-93.

21 Felson DT, Anderson JJ, Boers M, Bombardier C, Chernoff M, Fried B, et al. The American College of Rheumatology preliminary core set of disease activity measures for rheumatoid arthritis clinical trials. Arthritis Rheum 1993:36:729-40

22 van der Heijde DM, van't Hof M, van Riel PL, van de Putte LB. Development of a disease activity score based on judgment in clinical practice by rheumatologists. J Rheumatol 1993;20:579-81.

23 Lockshin MD, Druzin ML, Qamar T. Prednisone does not prevent recurren fetal death in women with antiphospholipid antibody. Am J Obstet Gynecol 1989; 160:439-43.

24 Isomäki P, Punnonen J. Pro- and anti-inflammatory cytokines in rheumatoid arthritis. Ann Med 1997;29:499-507.

25 De Vita S, Zaja F, Sacco S, De Candia A, Fanin R, Ferraccioli G. Efficacy of selective $B$ cell blockade in the treatment of rheumatoid arthritis: evidence for a pathogenetic role of B cells. Arthritis Rheum 2002;46:2029-33.

26 Dhavalkumar DP. B cell-ablative therapy for the treatment of autoimmune disease. Arthritis Rheum 2002;46:1984-5.

27 St Clair EW, Wagner CL, Fasanmade AA, Wang B, Schaible T, Kavanaugh A, et al. The relationship of serum infliximab concentrations to clinical improvement in rheumatoid arthritis: results from ATTRACT, a multicenter randomised, double-blind, placebo controlled trial. Arthritis Rheum 2002:46:1451-9 